\title{
CALCULATION OF THE MINIMAL LENGTH OF THE HIGH-SPEED LINE
}

\author{
Petr Nachtigall*, Erik Tischer \\ University of Pardubice, Jan Perner Transport Faculty, Department of Transport Technology and Control, \\ Studentská 95, 53210 Pardubice, Czech Republic \\ * corresponding author: petr.nachtigall@upce.cz
}

Abstract. This paper explores the minimum length of continuous sections of the high-speed line. The minimum length is examined in terms of the maximum speed of high-speed vehicles. Both traditional trainsets consisting of traction units and coaches, and train units were selected for examination. The graphs present the difference in the ability of the different vehicles to reach and use the maximum speed.

KEYWORDS: High-speed line, OpenTrack, simulation, track speed.

\section{INTRODUCTION}

The construction of a high-speed network is going to be a reality in the Czech Republic. After a long time of uncertainty, there is a real plan of activities that will make us part of the map of a high-speed railway. As the construction of the entire network will take a long time, this paper is trying to calculate the minimum length of a continuous line to make the high-speed traffic attractive for passengers. The OpenTrack simulation tool was used for simulation 1 . Subsequent calculations were performed in MS Excel. To find out which track length is effective for the defined maximum track speed, we analyzed rides of predefined trainsets on a hypothetical infrastructure.

The history of high-speed transport dates to the 20th century and has experienced its greatest upswing since the beginning of the 21st century. The total length of high-speed lines has already exceeded 50,000 $\mathrm{km}$ and it is planned to reach the target of 100,000 $\mathrm{km}$ in the next 15 years. As for individual countries, the most progressive country is China with its more than $35,000 \mathrm{~km}$, with a view to reaching $70,000 \mathrm{~km}$ by 2035 . Europe lags behind in this respect with about 9,000 km. The Czech Republic is still without a high-speed railway; however, pilot projects are already being implemented and some parts of the conventional infrastructure are being built to allow a speed of 200 $\mathrm{km} \cdot \mathrm{h}^{-1}$.

With the construction of the high-speed network, there comes the question of how long a section of the high-speed line must be to allow for the maximum track speed, making efficient use of the funds invested in this infrastructure [2, 3]. In their previous research, the authors investigated the optimum distance between two stops ensuring energy reliability. At the same time, they explored the effectiveness of introducing a speed of $200 \mathrm{~km} \cdot \mathrm{h}^{-1}$ on short sections of the conventional network. This paper examines the minimum length of a section of the high-speed line, which will enable the trains to reach the planned track speed. This problem is covered by the question of the efficiency of investment into the construction and operation of this specific infrastructure. There is a clear linear correlation between the track speed and construction, noise and safety measures. At the same time, a higher track speed puts stronger demands on vehicle design, power, and traction power consumption. A littler aside is the question of the minimum length of the high-speed line.

This research can be used in the preparation of HSL network 4] constructions or overall preparation of the systematic timetables [5]. The Czech Republic is not as big as for instance China, but during the expansion of the HSL network, we can use an optimization mathematical apparatus to ensure the maximum transportability and utility of the highspeed system [6, 7]. The issue of energy efficiency is dealt with in literature [8], describing the perspective of the use of the coasting and economic modes of high-speed trains. The question of the interlocking system is answered by the ETCS because the Czech Republic is going to install this system on the main corridors, including high-speed lines [9-14].

The costsÂăof infrastructure are figuratively paid by passengers in the price of the ticket, and this price should be in accordance with the travel time and the quality of service. Another important question is energy consumption. This issue is the focus of other papers [15-17].

\section{Preparation of the Simulation MODEL}

The OpenTrack simulation software was used for the research. The authors have been using this tool for a long time with good results, and this software is a globally established simulation tool [18. The model was designed with the emphasis on allowing all the trainset movements modelled to be performed in a very simple way. The simulation model was therefore 
prepared as simply as possible. The simulation model was created in two phases. In the first phase, an infrastructure model was created. The infrastructure model developed for this high-speed vehicle research consists of four tracks of $50 \mathrm{~km}$ each with no curves or slopes. In the second phase, the parameters of each trainset were entered. Most important are the tractive characteristics of trainsets, maximum speed, weight, adhesive weight, and vehicle resistance. As for the research trainsets, the 151.0 engine with $7 \mathrm{Bmz}$ coaches, Škoda 109E with 7 Bmz coaches, Siemens Viaggio Comfort non-traction unit with Taurus engine and multiple units of the 680 C̆D "Pendolino" series, AVE, and ICE 3 were chosen. For a more detailed description of the model, see previous article [19].

What is important for the actual simulation are the input characteristics of the individual trainsets. These characteristics are provided for in the following Table 1

To calculate the rolling resistance of the individual trainsets, the Davis equation was used, as expressed in Equation 1. The individual parameters are included in the vehicle database within the OpenTrack system used for the simulation. Had there been tunnels on the line, we would have had to add resistance caused by using the tunnel. However, no tunnel was included in the model.

$$
R_{L Z}=A+B * \nu+C * \nu^{2}[N]
$$

Where:

$R_{L Z}=$ train air resistance $[\mathrm{N}]$, $\nu=$ train speed $\left[\mathrm{km} \cdot \mathrm{h}^{-1}\right]$,

$\mathrm{A}, \mathrm{B}, \mathrm{C}=$ parameters.

The simulation was running continuously. Depending on the required accuracy [20, it was possible to establish the situation of the train in every moment in time. This is important in examining the impact of variables that can be easily included in our generic model, as appropriate. The actual train speed and distance covered can be calculated using integration according to Equation 2 and 3 . The resulting values can be used to create tachograph curves or the monitored parts thereof.

$$
\begin{gathered}
\nu=\nu_{p}+\int_{t_{1}}^{t_{2}} a \cdot d t\left[m \cdot s^{-1}\right] \\
s=s_{p}+\int_{t_{1}}^{t_{2}} \nu \cdot d t[m]
\end{gathered}
$$

Where:

$$
\begin{aligned}
& \nu=\text { speed }\left[\mathrm{m} \cdot \mathrm{s}^{-1}\right], \\
& \nu_{p}=\text { initial speed }\left[\mathrm{m} \cdot \mathrm{s}^{-1}\right], \\
& t=\text { time }[\mathrm{s}], \\
& t_{1}=\text { initial time }[\mathrm{s}], \\
& t_{2}=\text { target time }[\mathrm{s}],
\end{aligned}
$$

$a=$ acceleration $\left[\mathrm{m} \cdot \mathrm{s}^{-2}\right]$,

$s=$ distance covered $[\mathrm{m}]$,

$s_{p}=$ initial distance covered $[\mathrm{m}]$.

All simulations were carried out under good adhesion conditions; the value of adhesion was set at $100 \%$ of the adhesion coefficient. By setting the value of adhesion utilization, it is possible to simulate potential degraded adhesion conditions. The adhesion coefficient can be calculated according to Equation 4

$$
\mu=\frac{2.1\left[m \cdot s^{-1}\right]}{\nu+12.2\left[m \cdot s^{-1}\right]}[-]
$$

Where:

$\mu=$ adhesion coefficient,

$\nu=\operatorname{speed}\left[\mathrm{m} \cdot \mathrm{s}^{-1}\right]$.

Through the simulation, the authors intended to show the distance needed for the acceleration of each trainset. Each trainset was simulated with its maximum speed.

\section{Results}

The output of the simulation is quite simple: it is a distance-speed graph for each trainset, where we can observe the basic dynamic characteristics. Table 2 shows the distance necessary for a trainset to reach the speed limit.

The distance required for acceleration varies greatly. It certainly depends on the tractive power of each trainset and its weight. Based on this, a graph of the speed-distance dependence was created. Figure 1 shows this graph illustrating the curve for each trainset.

We can see that the minimum length of the highspeed line for a train to reach the limit of $200 \mathrm{~km} \cdot \mathrm{h}^{-1}$ lies between 4 and $10 \mathrm{~km}$. If we consider a speed limit of $230 \mathrm{~km} \cdot \mathrm{h}^{-1}$, this distance will increase to $8 \mathrm{~km}$ for ICE 3 and to $18 \mathrm{~km}$ for Pendolino and Railjet.ÂăOn the other hand, those values are just minimum ones. The actual length for practical useÂăshould be higher.

Another very important variable is acceleration. For the presentation of results, the trainsets were divided into two groups with a distance-speed graph created for each of them. Shown in Figure 11, the one group involves typical trainsets with a locomotive. The other group in Figure 3 contains train units. It is clear that the modern RailJet vehicles and locomotive 380 achieve much better results than a locomotive representing the older generation 151.0. Particularly at lower speeds, both these modern locomotives have dynamic properties close to those of train units.

Clearly the weakest out of the train units is Pendolino, which is mainly due to its older design and, therefore, its higher weight. Even on a straight section, Pendolino's maximum acceleration is $0.45 \mathrm{~m} \cdot \mathrm{s}^{-2}$ and declines relatively quickly. Starting at a distance of approximately $1 \mathrm{~km}$ (at approx. $100 \mathrm{~km} \cdot \mathrm{h}^{-1}$ ), its acceleration is already lower than $0.3 \mathrm{~m} \cdot \mathrm{s}^{-2}$. 


\begin{tabular}{|c|c|c|c|c|c|c|}
\hline Trainset & $\begin{array}{l}\text { Maximum } \\
\text { speed } \\
{\left[\mathrm{km} \cdot \mathrm{h}^{-1}\right]}\end{array}$ & Weight [t] & $\begin{array}{l}\text { Maximum } \\
\text { tractive } \\
\text { effort }[\mathrm{kN}]\end{array}$ & $\begin{array}{l}\text { Maximum } \\
\text { power }[\mathrm{kW}]\end{array}$ & $\begin{array}{l}\text { Maximum accel- } \\
\text { eration }\left[\mathrm{m} \cdot \mathrm{s}^{-2}\right]\end{array}$ & $\begin{array}{l}\text { Average decelera- } \\
\text { tion }\left[\mathrm{m} \cdot \mathrm{s}^{-2}\right]\end{array}$ \\
\hline $\begin{array}{l}151.0+7 \\
\text { coaches }\end{array}$ & 160 & 443 & 210 & 4000 & 0.353 & -0.6 \\
\hline $\begin{array}{lr}\text { Škoda } & 109 \\
\text { E }+ & 7 \\
\text { coaches } & \\
\end{array}$ & 200 & 445 & 274 & 6400 & 0.560 & -0.6 \\
\hline $\begin{array}{l}\text { Siemens } \\
\text { Viaggio } \\
\text { Comfort }\end{array}$ & 230 & 437 & 300 & 6400 & 0.627 & -0.6 \\
\hline AVE S-102 & 300 & 355 & 200 & 8800 & 0.526 & -0.6 \\
\hline Pendolino & 230 & 384 & 200 & 3920 & 0.461 & -0.6 \\
\hline ICE 3 & 300 & 463 & 300 & 8000 & 0.581 & -0.6 \\
\hline
\end{tabular}

TABLE 1. Basic characteristics of the vehicles simulated, source: Authors.

\begin{tabular}{ccccccc}
\hline Speed & \multicolumn{5}{c}{ Distance [m] } \\
{$\left[\begin{array}{ccccc}\left.\mathrm{km} \cdot \mathbf{h}^{-1}\right] \\
\right.$\cline { 2 - 6 }\end{array}} & Engine 380 & Engine 151.0 & RailJet & AVE & Pendolino & ICE 3 \\
\hline $\mathbf{1 0 0}$ & 890 & 1573 & 737 & 860 & 970 & 730 \\
\hline $\mathbf{1 6 0}$ & 2993 & 5284 & 2967 & 2610 & 4096 & 2280 \\
\hline $\mathbf{2 0 0}$ & 6588 & & 6914 & 4900 & 9400 & 4450 \\
\hline $\mathbf{2 3 0}$ & & 20804 & 8950 & 18247 & 7100 \\
\hline $\mathbf{3 0 0}$ & & & & & 20612 \\
\hline $\mathbf{3 3 0}$ & & & & & 36372 \\
\hline
\end{tabular}

TABle 2. Distance to be covered to reach the respective speed, source: Authors.

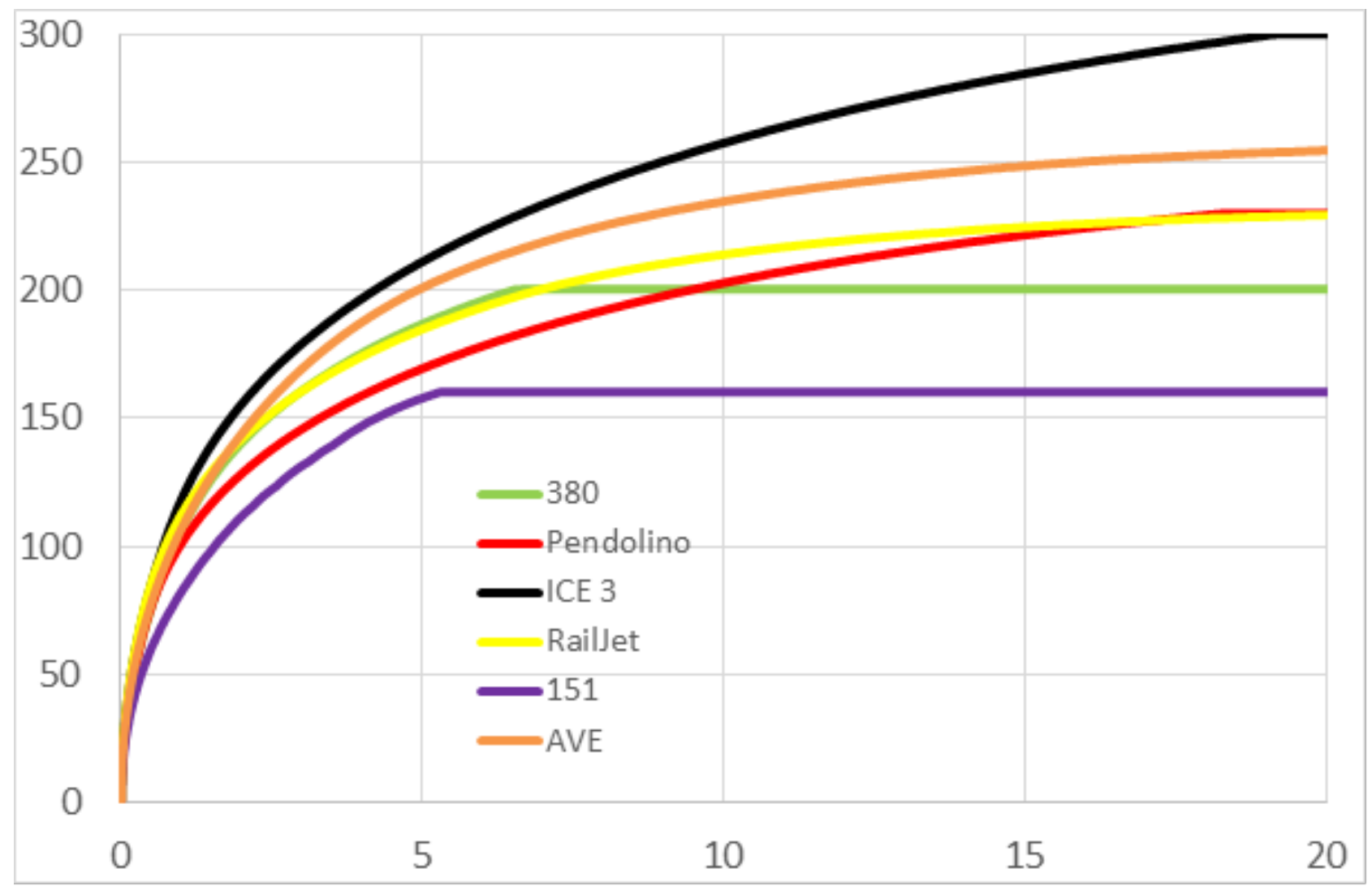

FiguRE 1. The distance needed for acceleration [km], source: Authors. 


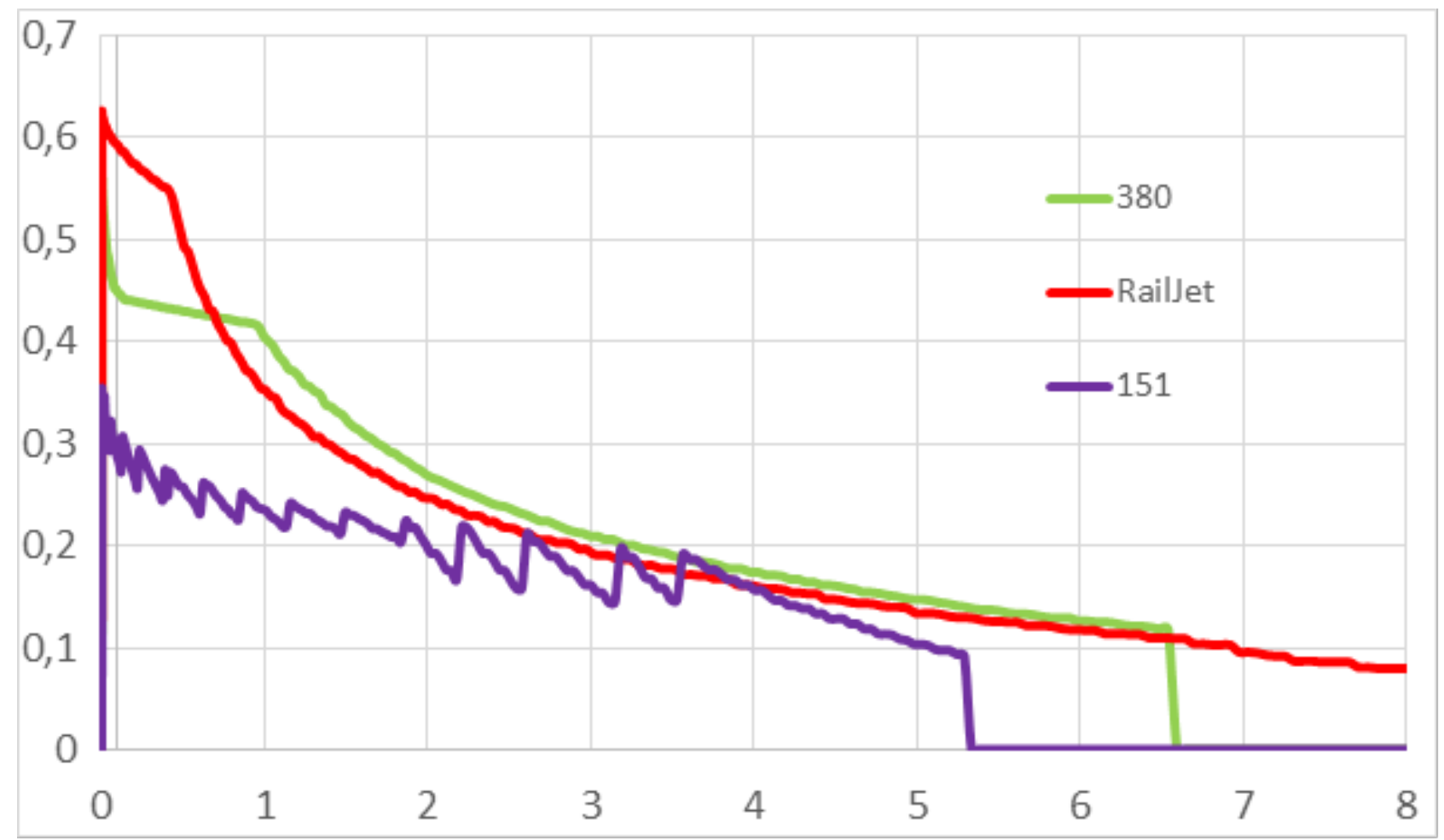

Figure 2. Acceleration of typical trainsets $\left[\mathrm{m} \cdot \mathrm{s}^{-2}\right]$, source: Authors.

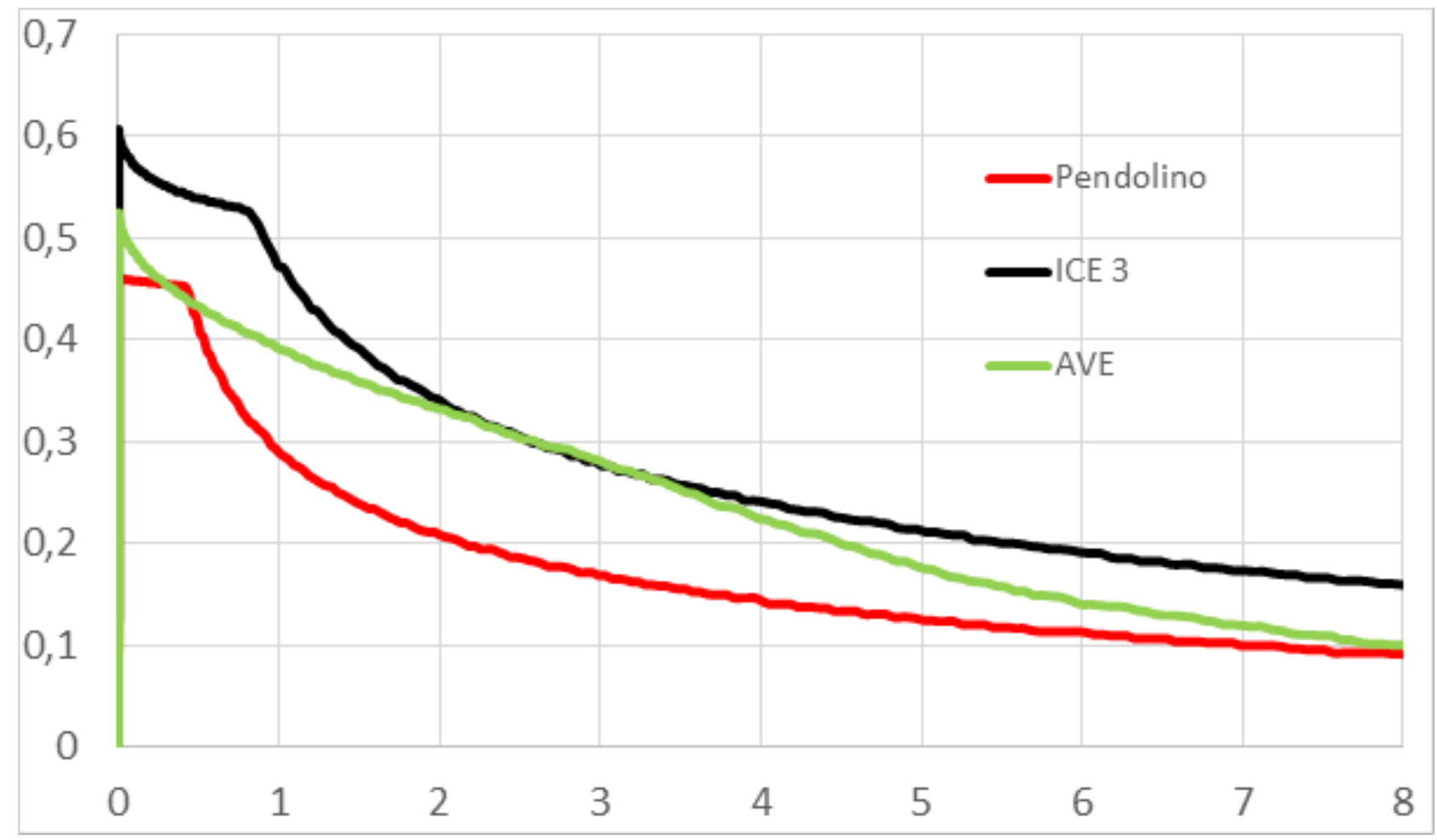

FiguRE 3. Acceleration of units $\left[\mathrm{m} \cdot \mathrm{s}^{-2}\right]$, source: Authors. 


\section{Conclusions}

This paper explores the minimum length of a section of the high-speed line for vehicles to be able to reach the maximum speed. The simulation showed that for a maximum speed of $230 \mathrm{~km} \cdot \mathrm{h}^{-1}$, this distance is approximately 10 to 15 kilometers. This is the distance to be covered by high-speed units to achieve this speed. An important question to be answered before the line construction is whether the line would only be used by high-speed units, or also by conventional trainsets with a maximum speed of 200 or $230 \mathrm{~km} \cdot \mathrm{h}^{-1}$. The simulation shows that even these trainsets can achieve their respective maximum speeds in a relatively short period of time. By contrast, older models of traction units are not suitable for operation on these newly constructed lines due to their low maximum speed and traction characteristics. Encouraging is the fact that even short sections of the high-speed line are a convenient and efficient tool for the development of the railway network: not only are they parts of the high-speed network, but they can also take the strain off current conventional lines. Mainly close to major urban areas, the capacity of these lines is often saturated, and they are not able to cover the ever-increasing demand for suburban transport. Also freight railway undertakings are waiting for the clearing of these sections.

\section{ACKNOWLEDGEMENTS}

This article is published within realization of the project "Cooperation in Applied Research between the University of Pardubice and companies in the Field of Positioning, Detection and Simulation Technology for Transport Systems (PosiTrans)", registration No.: CZ.02.1.01/0.0/0.0/17_049/0008394.

\section{REFERENCES}

[1] D. Huerlimann, A. Nash. OPENTRACK Simulation of Railway Networks Version 1.3. Zurich: ETH Zurich, Institute of Transport Planning and Systems, 2019.

[2] J. Siroky, P. Sramek, K. Magdechova, et al. Timetable performance evaluation. Transport Means -

Proceedings of the International Conference, 2019-October [online] 10 2019, [Cited: 4 21, 2020], https://www.scopus.com/record/display.uri?eid= 2-s2.0-85074278851\&origin=resultslist

[3] C. Blanquart, M. Koning. The local economic impacts of high-speed railways: theories and facts. European Transport Research Review . [Online] 2017. [Cited: 2 20, 2020.] https://link.springer.com/article/10.1007/ s12544-017-0233-0.

[4] Postup přípravy výstavby vysokorychlostních tratí. Správa železnic, s.o. [Online] 11 2019. [Cited: 02 10, 2020.] https :

//www.szdc.cz/vrt/co-je-vrt/postup-pripravy-vrt

[5] J. Sůra. Správa železnic otestovala $200 \mathrm{~km} / \mathrm{h}$ na české železnici. Vyšší rychlost nechce za každou cenu. Z dopravy.cz. [Online] Avizer Z, s.r.o., 01 13, 2020. [Cited: 02 19, 2020.] https://zdopravy.cz/sprava-zeleznicotestovala-200-km-h-na-ceske-zeleznici-vyssirychlost-nechce-za-kazdou-cenu-40207/
[6] J. Wang, spol. Optimizing High-Speed Railroad Timetable with Passenger and Station Service Demands: A Case Study in the Wuhan-Guangzhou Corridor. Journal of Advanced Transportation. [Online] 09 24, 2018. [Cited: 02 15, 2020.], https://doi.org/10.1155/2018/4530787

[7] Y. Wang, spol. Optimization of High-Speed Railway Line Planning Considering Extra-Long Distance Transportation. Journal of Advanced Transportation. [Online] 01 13, 2020. [Cited: 02 20, 2020.], https://doi.org/10.1155/2020/3062891

[8] A. Zurkowski. Traction power consumption as a component of maximum. MATEC Web of Conferences 180. [Online] 2018. [Cited: 3 15, 2020.], https://doi.org/10.1051/matecconf/201818001009

[9] J. Marek. Brzdný model ERTMS/ETCS a možnosti jeho optimalizace na úrovni aplikace. Vědeckotechnický sborník ČD. [Online] Červenec 2019. [Cited: 0120 , 2020.] https://vts.cd.cz/documents/168518/233051/ 01_4719_Marek_Brzdny+model+ERTMS_ETCS+a+ moznosti+jeho+optimalizace_kor.pdf/b12d3378d3e6-4d06-8feb-b5ba5a15605c

[10] Konference Správy železniční dopravní cesty, s.o., Informace z UNISIG, aktuální stav specifikací a další rozvoj etcs. ACRI. [Online] 06 02, 2015. [Cited: 02 04, 2016.] www.acri.cz

[11] P. Nachtigall, J. Ouředníček. Wider aspects of deceleration supervision in ERTMS/ETCS. Matec Web of Conferences. [Online] 10 12, 2018. [Cited: 01 17, 2020.], https://doi.org/10.1051/matecconf/201823500010.

[12] P. Nachtigall. Vliv nastavení mobilní části ETCS na brzdnou křivku. Perner's Contacts. 4 22, 2016, pp. $131-138$.

[13] J. Ouředníček, P. Nachtigall. Zajištění dohledu nad zastavením (snížením rychlosti) v ERTMS/ETCS v souvislostech. Vědeckotechnický sborník ČD. [Online] ČD, a.s., Červenec 2019. [Cited: 01 15, 2020.] https://vts.cd.cz/documents/168518/233051/ 11_4719_Nachtigall\%2C+Ourednicek_Zajisteni+ dohledu+nad+zastavenim+(snizenim+rychlosti)+v+ ERTMSETCS+v+souvislostech_kor.pdf/bf57499e-aac14a0f-9ebd-b523361d694a.

[14] I. Hruban, P. Nachtigall, O. Štěpán. Přínosy zavedení ETCS z pohledu brzdných křivek. Vědeckotechnický sborní ČD. 2015, Vol. 40.

[15] A. Fernández-Rodríguez, spol. Balancing energy consumption and risk of delay in high speed trains: A three-objective real-time eco-driving algorithm with fuzzy parameters. Transportation Research Part C. [Online] 08 29, 2018. [Cited: 01 28, 2020.], https://doi.org/10.1016/j.trc.2018.08.009.0968-090X

[16] Z. Hiuru, J. Limin, W. Li, X. Xinyue. Energy consumption optimization of train operation for railway systems: Algorithm development and real-world case study. Journal of Cleaner Production. [Online] 14 , 2019. [Cited: 3 15, 2020.], https://doi.org/10.1016/j.jclepro.2019.01.023

[17] Y. Chen, H. Guo, H. H. Study on energy consumption of multi-trains tracking on long heavy. IOP Conference Series: Earth and Environmental Science. [Online] 2019. [Cited: 17 3, 2020.] https://iopscience.iop.org/ article/10.1088/1755-1315/267/4/042029/pdf. 
[18] J. Široký, E. Tischer, P. Nachtigall. The use of simulation modelling for determining the capacity of railway lines in the Czech conditions. Warsaw: DE GRUYTER, 2020. Open Engineering. pp. 224-231.

[19] P. Nachtigall, E. Tischer. Efficiency of increasing of the track speed using simulation in Opentrack. Proceedings of the 32nd European Modeling \& Simulation Symposium (EMSS 2020), https : //www.cal-tek.eu/proceedings/i3m/2020/emss/017/ ISSN 2724-0029.

[20] J. Bulíček. Cancellation of delayed trains: passengers' and capacity points of view. Žilina: MATEC Web.

Conf., 2018. Vol. 235. 